\title{
A Study in Teacher Education: Effects of Activity-Based Instruction on Student Teachers' Achievement ${ }^{1}$
}

\section{Öğretmen Eğitiminde Bir Araştırma: Etkinliklere Dayalı Öğretimin Öğretmen Adaylarının Başarısındaki Etkisi}

\author{
Melek Çakmak, Gazi Faculty of Education, melek@gazi.edu.tr
}

\begin{abstract}
Activity-based instruction is one of the teaching approaches used in teacher education. This study aims to examine the effects of activity-based instruction on the views and learning outcomes of the student teachers. To this end, activity-based instruction approach was applied during the instruction on the experimental group and traditional learning method was applied on the control group. Poster study, puzzle and card activity were the main activities used for instruction in the experimental group during the study. The results showed no significant difference in the pre-test scores and the post-test scores between experimental and control groups. These statistical results are different from those found in similar studies, which is found to be worthy of consideration in the context of effective teacher education to be evaluated. Keywords: Activity-based instruction, student teacher, teacher education.

öZ. Etkinliklere dayalı öğretim, öğretmen eğitiminde öğretmen adaylarının eğitimi için kullanılan öğretim yaklaşımlarından biridir. Bu çalışma öğretmen adaylarının öğrenme ürünleri ve bakış açılarında etkinliklere dayalı öğretimin etkisini sınamayı amaçlamıştır. Bu amaca ulaşmak için, deney grubunda etkinliklere dayalı öğretim, kontrol grubunda ise geleneksel öğrenme yaklaşımı kullanılmıştır. Deney grubunda poster çalışması, bulmaca ve kart etkinliği öğretimde kullanılan temel etkinlikler olmuştur. Araştırmanın sonuçları, deney ve kontrol gruplarının ön test ve son test puanları arasında anlamlı bir farklılık olmadığını göstermiştir. Araştırmanın istatistiksel sonuçları benzer çalışmalardan farklı olup, etkili öğretmen eğitimi bağlamında değerlendirilmek üzere dikkate değer bulunmuştur.

Anahtar Kelimeler: Etkinliklere dayalı öğretim, öğretmen adayı, öğretmen eğitimi.
\end{abstract}

\section{INTRODUCTION}

One of the aims of teacher education programs is to prepare student teachers for the teaching profession in the best way. This aim can manifest when many constituents are at work in the education of student teachers. A teacher must have three types of knowledge: subject knowledge, general pedagogical knowledge and knowledge of general culture (Küçükahmet, 2000). In a sense, preparation for the teaching profession requires acquisition of this knowledge and skills (Saban, 2003). Distribution of these three types of knowledge is different in intensity at different levels of schooling. Shulman (1987) suggests that there are seven types of knowledge which teachers use during teaching: content knowledge, general pedagogical knowledge, curriculum knowledge, pedagogical content knowledge, knowledge of learner characteristics, knowledge of educational context and knowledge of educational goals and values. This viewpoint aids us in examining this area with a rich perspective. Nevertheless, it seems open to discussion for teachers who will serve, for instance, at the primary level because at this stage different learning needs of students in different stages come to the forefront. Tamir (1988) also makes a similar classification with six types of knowledge: general liberal education, personal performance, content knowledge, general pedagogical knowledge, content-specific pedagogical knowledge, and foundations of teaching profession. Grossman (1990) has developed a model, which suggests that teachers should have pedagogical content knowledge. This implies that knowledge of the content and pedagogy are necessary for teachers. On the other hand, according to Reynolds (1989; cited in Vries and Beijaard, 1999, p.375) the knowledge base for beginning teachers should consist of knowledge about different views on teaching, the teaching profession, learning, children's development, classroom management, classroom organization, curriculum, characteristics of subjects and their

1 The earlier version of the study was presented at INCCUI (05-08 October, 2011) held by Anadolu University in Eskișehir, Türkiye. 
contents, pedagogy, general aspects of the basics, and school and education in social, sociological, and political contexts. Teachers of the future will need all the above mentioned knowledge types as student teachers. For this reason, teacher education is of utmost importance for student teachers. Awareness of this brings about a responsibility on educational systems to continually revise and renovate themselves through developments. In a sense, the courses that are in the teacher education curricula play a significant role in this process. As Özgün-Koca and Şen (2006) have noted, teacher educators and researchers have been continuously evaluating ways to improve teacher education programs in order for pre-service teachers to be well prepared to enter the field. According to Briggs (2005), changes in higher education including changes in funding, competition amongst institutions, the increased use of technology and a shift to learner centred education are combining to change the roles of both universities and academics. Based on this statement, new innovations and developments might also affect intsructors' teaching strategies at higher education. As it is indicated in the study of Yayll (2008) "Recently, there has been a movement from what to teach towards how to teach in teacher education (Anders, Hoffman, \& Duffy, 2000; Short \& Burke, 1989; Zeichner, 1983) in order to better understand the real classroom conditions. The new paradigm is backed up by the constructivist theory of teaching and learning methodology, which values learner centred initiative in education, through which a successful learner constructs knowledge in a meaningful way. This requires learning to be an active and social process". Ovando (2001) states that the main focus of a learner-centred system is the learner as also emphasized in the studies regarding with active learning process and constructivist approach. Niemi (2002) stated that active learning strategies emphasize constructivist qualities in knowledge processing. Active learning is based on learner-centred learning, whereby the learner acts as the active participant and the teacher as the guide. Carwile (2007) highlights within the constructivist model that the learner is not a passive recipient but rather the centre of instruction. As Lunenberg and Korthagen (2003) indicate that learning is considered an active process in which the learner builds up personal knowledge representations. Chen (2003) states that the use of the constructivist approach challenges teachers to provide techniques that support students' construction of their understanding. It is believed that methods which are in compliance with the constructivist learning approach should be used as it is viewed that this approach enables students to learn more effectively by way of constructing their own knowledge (Aydın and Balım, 2005).

Numerous factors play a role in realizing active learning. Such factors as teaching atmosphere, classroom organization, and effective use of technology, use of various techniques in assessment, and instructional methods and techniques are important in active learning. Instructional activities, in particular, have an important role within the implementation process of teaching methods that adopt active learning particularly. One factor to aid the implementation of active learning is to choose suitable activities in the teaching and learning process so that activities have an assistive, or supportive - reinforcing effect for teachers. Activity-based instruction might be one way to facilitate active learning. Activity-based learning has important contributions to learning within the instructional process. Activities can contribute to the cognitive learning domain by facilitating learning to be permanent and reinforcing knowledge; to the affective learning domain by instilling more self-esteem towards learning and showing more interest in what the student is doing; and the social and psychomotor domains by providing group-work and sharing. The methods used in traditional teaching are very different from those employed in active learning. In traditional instruction, the teacher is active and the learner is passive. The main strategy is to transfer knowledge by the teacher to the learner group. The teacher uses the classic method, in other words, the direct explanation method, while having students take notes from time to time. Mcalpine's (2004) statement on education seems to support these methods:

Instruction usually involves informing at some point, both oral and written because written information provides students with reference materials for later use, and oral representation provides students with opportunities to clarify expectations and misconceptions. This essential but insufficient element of 
instruction can involve subject matter, for instance, introducing the main ideas

in a paper in class and then having students read it out-of-class (p.127-128).

Undoubtedly, effective use of any method in the instructional process is directly related to the principles and preparations that the method calls for. When a method is not used effectively, it is not surprising to encounter some limitations from the teachers or the students' viewpoints. For example, when straightforward lecturing is not used effectively, it may be perceived to be boring and routine to students. Maclellan (2005) also indicates that student motivation is an extremely important issue for instructors in higher education. In a sense, educators are influential in achieving a successful teacher training process. Professors must use their knowledge of these factors to construct classroom activities that maximize student involvement in the learning process in order to enhance the student motivation to learn (Hancock, 2007, p.229). As Niemi (2002) indicated, promoting active learning in classrooms shapes the teachers' role into that of a facilitator, who assigns more responsibility to students. Techniques, methods, and activities they use have an important effect on student teachers and their learning. Zeichner (2005) states that "methods instructors at the university should discuss how and when teachers would choose to do certain things and how they can adapt them to particular circumstances. In sum, in teacher education programs, the use of various and innovative teaching methods, approaches and strategies will help student teachers to form new ideas in their own teaching. As emphasized in some studies (e.g. Gore, Griffiths and Ladwig, 2004) teacher educators try new things for better teaching. As mentioned earlier in the present study, one of the approaches that can be adopted in teacher education is activity-based instruction. In this study, activity-based instruction was planned and used.

This study mainly aimed to examine the effects of activity-based instruction on the student teachers' achievement. To this end, this study was designed to answer the following questions:

1. Is there a statistically significant difference between the experimental and the control group in terms of the mean pre-test scores?

2. Is there a statistically significant difference between the experimental and the control group in terms of the mean post-test scores?

3. Is there a statistically significant difference between the pre-test and the post-test mean scores of the experimental group?

4. Is there a statistically significant difference between the pre-test and the post-test mean scores of the control group?

5. What are the views of the student teachers about teaching approaches and practices used in the experimental group?

\section{METHOD}

Both qualitative and quantitative research methods were used in the study. An experimental design with pre-test/post-test and control group was employed. Traditional lectures were delivered to the control group. The experimental group, on the other hand, was provided with activity-based instruction. The independent variable of the study was the teaching method. The dependent variables were pre and post test results of "Teaching Methods Test". In the experimental group activity-based activities were used in addition to lecturing whereas only lecturing was used in the instructional process of the control group. This might also be accepted as the limitation of the study. It should be stated at this point that the researcher does not aim to make generalizations. The study undertakes the topic within a limit through an experimental approach, to test the achievement of student teachers who receive activity-based instruction and to present a general perspective of the student teachers' views towards activities.

\section{Study Sample}

The study group comprised the student teachers who registered to and attended the course "Planning and Evaluation in Instruction" in the summer semester of 2006-2007 academic years at Gazi University in Turkey. The groups were determined as the experimental and the control groups. The experimental group comprised 24 and the control group comprised 26 students. The common characteristic of the students in both groups was that they had completed 
their third year in the teacher education program. This also shows that student teachers were experienced in active learning and instructional activities.

\section{Data Sources}

Firstly, the sample's gain on teaching methods was identified. Next, a multiple-choice test was developed on teaching methods by the researcher. The test included 25 items which had four alternatives. The test was revised and finalized based on the reviews of field specialists. Then, it was used in a pilot study to test its reliability. The pilot study included seventy-four student teachers and the KR-20 test (Kuder Richardson test) indicated that five items (items 4, 8, 13, 14 and 21) were not suitable. After the elimination of these items, the reliability coefficient of the test was found to be .69. The test was administered to the experimental group and the control group as a pre-test. Both groups included student teachers and the test was administered during the summer term of 2006-2007 academic years as can be seen in the research model given in Table 1. The study lasted for 15 hours in three weeks.

Table 1. Research Model

\begin{tabular}{llll}
\hline Group & Pre-test & Method used & Post-test \\
\hline Experimental & Teaching methods test & $\begin{array}{l}\text { Traditional teaching }+ \\
\text { Activity-based } \\
\text { approach }\end{array}$ & Teaching methods test \\
\hline Control & Teaching methods test & Traditional teaching & Teaching methods test \\
\hline
\end{tabular}

Finally, one open-ended question was used to collect the views of student teachers in the experimental group related to learning by activities after the treatments. The treatment process and procedure of this study can be summarized as below. The treatments were delivered to two different groups which were taught the course "Planning and Evaluation in Instruction" by the researcher. The treatment was applied during the "teaching methods" part within the content of the course. The reason for selecting this part was to provide effective instruction to student teachers particularly on this topic, which they view as significant in their own development and therefore have a higher motivation to study this topic. The pre-test related to the topic (which will be detailed in the data sources section) was administered to both groups before the content was introduced. As a result of the statistical study, no difference was found between the two groups according to the pre-test results. This proved that the groups were equal, as a result of which the topic was presented to both groups as planned.

In the experimental group, the content was presented through activity-based instructional method within a period of three weeks. The activities used in the experimental group were effective activities: card activity, puzzle and poster. In fact, many types of active learning strategies, techniques or methods such as writing activities, brainstorming, games, debates, group work, case studies, questions and answers, flash cards, concept mapping, flowcharts, models, student-created charts, matrices, problem-based learning, can be used in activity-based instruction

process

(http://trc.ucdavis.edu/TRC/ta/tatips/activelearning.pdf;http://www.teachtech.ilstu.edu/addit ional/tips/newActive.php; http://www.indiana.edu/ icy/document/active_learning_techniques .pdf). In this study, only several of them (card activity, puzzle and poster) were decide to use in teaching. The activities used in this research are explained below briefly.

\section{Card activity}

After teaching methods as course content were presented, the student teachers were presented with cards (at least ten cards to each student teacher). Then, the student teachers were asked to develop questions on the teaching methods that they had studied and to write them on the cards. After that, they were asked to discuss and answer the questions in groups. Through this activity, the student teachers were provided with the opportunity to remember and retain the content through enjoyment. 


\section{Puzzle}

After content of the teaching methods was completed, the student teachers were asked to develop a jigsaw puzzle on these methods. This puzzle included their questions on the related teaching methods. The number of questions to include was restricted to fifteen. The student teachers completed the design of the puzzle and the questions in the class. Next, they were asked to bring their completed puzzles. The student teachers worked in groups of five. Then, they exchanged the puzzles. This made it possible to solve different puzzles. It was observed that the student teachers enjoyed the activity as they reviewed the content and shared their information. Later, the most interesting and creative puzzle from each group was displayed to the whole class.

\section{Poster}

The students were asked to review the related literature and bring the studies which were significant, or interesting, or which they considered as different. They were instructed to complete this task individually. Later, they worked in groups of five to select articles. Then, they produced their posters. It was observed that the participants liked the activity. During the period of these treatments, an atmosphere of effective communication and interaction was shared between the researcher (who was also the instructor) and the students in the experimental group. It was also observed that the student teachers were involved in the activities with interest and completed them with enthusiasm. It can be stated that this condition affected the instruction and the process positively. Meanwhile, the researcher did not implement a treatment during the three week period of instruction in the control group other than presenting the content in the classical manner. During the period of content presentation to this group, the researcher employed the lecturing and question-answer methods to support the instruction. No considerable problem was observed in this group, either, on the contrary, it was felt that the student teachers showed interest in the lesson. However, compared to the experimental group, the most important difference was that all the students in the experimental group were involved in the activities and therefore they actively participated in the lesson; while in the control group, the students were observed to listen to the lesson but they were not active participants of the lesson.

\section{Data Analysis Techniques}

The Statistical Package for the Social Scientists (SPSS) 10.0 was used for the statistical analysis procedures in the data analysis. Before presenting the results about research questions, the normality assumption is checked by using the Kolmogorov-Smirnov and Shapiro- Wilk tests. The test results are given in Table 2.

Table 2. The results of the Kolmogorov-Smirmov and Shapiro-Wilk tests of the groups' data

\begin{tabular}{cccccccc}
\hline \multirow{2}{*}{ Test } & \multirow{2}{*}{ Group } & \multicolumn{2}{c}{ Kolmogorov-Smirnov } & \multicolumn{3}{c}{ Shapiro-Wilk } \\
\cline { 3 - 7 } & & Statistic & $\mathrm{df}$ & $\mathrm{p}$ & Statistic & $\mathrm{df}$ & $\mathrm{p}$ \\
\hline \multirow{2}{*}{ Pre-test } & Experimental & 0.13 & 24 & .20 & 0.97 & 24 & .75 \\
& Control & 0.14 & 26 & .20 & 0.97 & 26 & .67 \\
\hline \multirow{2}{*}{ Post-test } & Experimental & 0.12 & 24 & .20 & 0.95 & 24 & .22 \\
& Control & 0.14 & 26 & .20 & 0.95 & 26 & .23 \\
\hline
\end{tabular}

The results of both Kolmogorov-Smirnov and Shapiro-Wilk tests failed to reject the null hypotheses that the groups' data normally distribute $(p>.05)$. In order words, the data normally distribute. Since the data normally distribute, the hypotheses were tested with the parametric tests. 


\section{FINDINGS AND INTERPRETINGS}

The groups' pre-test data were analysed with the t-test for independent samples. The analyse result were presented in Table 3.

Table 3. Results of the t-test for independent samples of the groups' pre-test data.

\begin{tabular}{lcccccc}
\hline Group & $\mathrm{n}$ & $\overline{\mathrm{X}}$ & $\mathrm{SD}$ & $\mathrm{df}$ & $\mathrm{t}$ & $\mathrm{p}$ \\
\hline Experimental & 24 & 10.33 & 2.70 & \multirow{2}{*}{48} & \multirow{2}{*}{1.64} & .108 \\
Control & 26 & 9.12 & 2.57 & & \\
\hline
\end{tabular}

According to the results of the t-test for independent samples, there was no significant difference between the groups' means of pre-test data, $t(48)=1.64, p=.108$. Since the groups were equal in the pre-test scores, their post-test scores were also compared by the t-test for independent samples, The results of the t-test for independent samples were given in Table 4.

Table 4. Results of the t-test for independent samples of the groups' post-test data.

\begin{tabular}{lcccccc}
\hline Group & $\mathrm{n}$ & $\overline{\mathrm{X}}$ & $\mathrm{SD}$ & $\mathrm{df}$ & $\mathrm{t}$ & $\mathrm{p}$ \\
\hline Experimental & 24 & 13.12 & 2.13 & \multirow{2}{*}{48} & 0.70 & .490 \\
Control & 26 & 12.96 & 2.47 & & \\
\hline
\end{tabular}

According to the results of the t-test for independent samples, there was no significant difference between the groups' means of post-test data, $t(48)=0.70, p=.490$. In other words, the method in the experimental group was effective. The experimental group's means of pre-test and post-test were compared by the t-test for paired groups. The results of the test were given in Table 5.

Table 5. Results of the t-test for paired groups of the experimental group's data of pre-test and posttest.

\begin{tabular}{lcccccc}
\hline Test & $\mathrm{n}$ & $\overline{\mathrm{X}}$ & $\mathrm{SD}$ & $\mathrm{df}$ & $\mathrm{t}$ & $\mathrm{p}$ \\
\hline Pre-test & 24 & 10.33 & 2.69 & 23 & -4.24 & .000 \\
$\quad$ Post-test & 24 & 13.42 & 2.12 & 23 & \\
\hline
\end{tabular}

According to the t-test for paired groups, there was significant difference between the experimental group's means of pre-test and post-test data, $\mathrm{t}(23)=-4.24, \mathrm{p}=.000$. In other words, the method in the experimental group was effective. In addition, the effect size eta-squared had a large value of .44. The control group's means of pre-test and post-test were compared by the ttest for paired groups. The results of the test were given in Table 6.

Table 6. Results of the t-test for paired groups of the control group's data of pre-test and post-test

\begin{tabular}{lcccccc}
\hline Test & $\mathrm{n}$ & $\overline{\mathrm{X}}$ & $\mathrm{SD}$ & $\mathrm{df}$ & $\mathrm{t}$ & $\mathrm{P}$ \\
\hline Pre-test & 26 & 9.12 & 2.56 & 25 & -6.62 & \multirow{2}{*}{.000} \\
$\quad$ Post-test & 26 & 12.96 & 2.47 & 25 & & \\
\hline
\end{tabular}

According to the t-test for paired groups, there was significant difference between the control group's means of pre-test and post-test data, $\mathrm{t}(23)=-6.62, \mathrm{p}=.000$. In other words, the method in the control group was effective. In addition, the effect size eta-squared had a large value of .64. In addition, the groups' means of pre-test and post-test were compared in Graph 1. 


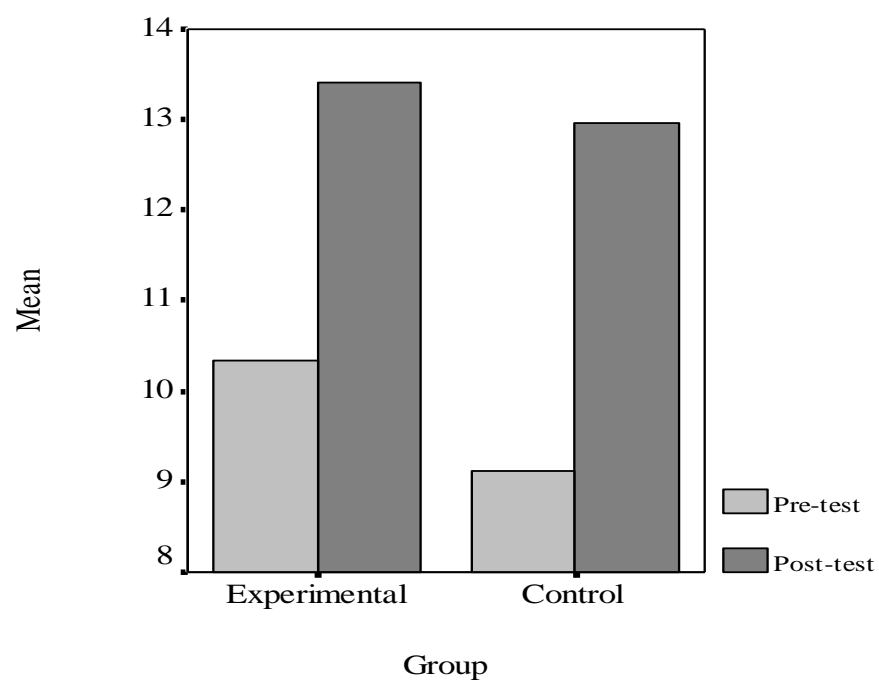

Graph 1. Comparison of the graph of means of the groups' pre-test and post-test

In the study, the views of the experimental participants about the activities used were also gathered. They were asked to write down their views briefly about the activities. It has been found that they generally have a positive attitude towards the activities. Several of the views are provided below:

It was an activity that improved our team work skills. While classifying the pictures and writings about the teaching methods, we had further information about them. It reinforced our knowledge. It was both an active and nice experience.

The project dealing with teaching methods was very enjoyable and informative. It made it possible to conduct research and to practice our skills. We learned what we should do while implementing a project.

I comprehended the teaching methods better. Group work was also very effective. We heard about different views. We produced something which was creative. We also learned about opposite views. We discussed to reach better ideas. We developed a visual educational device.

In my future professional life, I think that activities will attract the interest of the students to understand and grasp a subject. With the help of this study, I better realized the effect of visual elements on learning.

This procedure encouraged us to do research. Group-work was an additional positive side. I think that the ratio of retention in the mind of the teaching methods increases. It was very good.

Group work was very enjoyable. We learned how to support the topic with visuals, how to better present a topic and how to raise attention to the topic by doing the activities. When we studied the activities from the student point of view, we understood that visuals were very important. I think these activities were very beneficial and we can teach our students in the future by implementing similar activities.

We did group work and exchanged ideas in the activities. 
I found the opportunity to work with my friends in groups, to work harmoniously with my friends, and to enjoy the lesson. Moreover, we both learned and reinforced what we learned by doing activities.

I comprehended the teaching methods better with these activities. We started to think better by working in groups with friends. We learned different ideas. We constructed creative work. We discussed about better activities. We created both an educational and a visual tool.

The activities we did facilitated the comprehension and reinforcement of teaching methods fully. Lasting learning took place. We gained a different learning experience. I think it was both active and good work. Our research skills developed as well.

These views of the student teachers emphasize several points: enjoyable activities, efficiency of group work, discussions, and creative thinking. Niemi (2002) states that the processing of knowledge requires problem-solving orientation, a critical approach and an evaluation of knowledge in active learning. Niemi (2002) also points out that learning requires social skills which make them capable of social interaction. Student teachers in this present study also reported that such activities encourage several other skills such as poster presentation, forming groups, etc. In light of the results obtained from the experimental group, it can be stated that although activity-based instruction does not yield a statistically significant result on student achievement, student teachers views indicate that activity-based instruction enriches the teaching-learning process in various ways. On the other hand, student teachers in the control group were observed that they really enjoyed the instruction given them.

\section{DISCUSSION AND CONCLUSION}

This study was designed to determine whether or not activity-based teaching approach has a differential effect on the student teachers achievement in contrast to traditional teaching approach in this course. The results of the study showed that in terms of student achievement, no difference was found between activity-based teaching approach and traditional teaching approach in terms of the pre and post test results. The study also revealed that the student teachers liked the courses delivered through activity-based teaching and stated that they were given the opportunity to revise the content and to comprehend it. To provide a more detailed summary, the following results can be listed:

- First, no significant difference was found between the experimental and the control group in terms of mean pre-test scores. This result shows that the level of knowledge of the students in both groups was equal before the treatment.

- Second, no statistically significant difference was found between the experimental and the control group in terms of mean post-test scores. This result can be interpreted as an unexpected and interesting finding. In experimental studies, the results are generally to the advantage of the experimental group, therefore the group which receives treatment receives better results. However, in this study, the results did not yield this result statistically. Therefore, no significant difference was found between the post-test scores of the group which received activity-based instruction and those of the group which received traditional instruction. A few factors may have had an effect on this result. That the instruction was attended with interest by both group participants may be explained by their interest in the content whether they had to listen actively or passively. On the other hand, there may be an instructor effect. Even when different methods are used, it can be thought that different methods may have the same effect on the success of students if the methods are used effectively.

- Third, a statistically significant difference was found between pre-test and post-test mean scores of the experimental group. 
- Fourth, a statistically significant difference was found between pre-test and post-test mean scores of the control group. These results indicate that the instruction was effective in both the experimental and the control group.

- Fifth, student teachers have a variety of viewpoints about activities used in the study. The student teachers found the activities entertaining, informative and fostering creativity in general. This result shows that the student teachers evaluated the activities from the viewpoint of different dimensions rather than their cognitive benefits.

- The findings have also showed that both activity-based teaching and traditional teaching positively affected student achievement. This means that the use of this method had significance rather than the method itself. Thus, the student teachers should also be trained on how to employ teaching methods in an effective way.

- Finally, the conclusions of the study may be formulated into the following suggestions. Training provided to student teachers may affect their attitudes towards the profession of teaching and their teaching behaviour. Activity-based teaching has been given importance in recent years. This study also indicates that activity-based instruction is effective. Therefore, courses can also be delivered through activity-based instruction.

Teacher education programs should try to prepare student teachers for their profession. As Slick (1997, p.714; cited in Wilson, 2006) stated student teachers' preparation is considered "essential in training and helping future teachers develop pedagogical skills". Therefore, the courses that are included in the program are very significant. In the training of teachers, introducing the student teachers to the active learning techniques is an important dimension. It can be assumed that if student teachers start to teach with the knowledge of these techniques, they can accelerate the slow change in schools by implementing these techniques.

\section{REFERENCES}

Aydın, G. \& Balım, A.G. (2005). 'An interdisciplinary application based on constructivist approach: teaching of energy topics', Ankara University Journal of Faculty Educational Sciences, 38(2), 145-166.

Briggs, S. (2005). 'Changing roles and competencies of academics', Active Learning in Higher Education. 6(3), 256-268. http://alh.sagepub.com/cgi/content/abstract. (Retrieved on: September 19, 2007).

Carwile, J. (2007) 'A constructivist approach to online teaching and learning', Inquiry 12(1): 68-73.

Chen, C. (2003). 'A constructivist approach to teaching: implications in teaching computer networking information technology', Learning and Performance Journal, 21(2).

Gore, J. M. ; Griffiths, T. \&. Ladwig, J. G. (2004). Towards better teaching: productive pedagogy as a framework for teacher education. Teaching and Teacher Education 20, 375-387.

Grossman, P.L. (1990). The making of a teacher knowledge and teacher education. New York \& London: Teachers College Press.

Hancock, D.R. (2007). 'Effects of performance assessment on the achievement and motivation of graduate students', Active Learning in Higher Education 8(39), 219-231 (Retrieved on: November 12, 2007).

Küçükahmet, L. (2000). Öğretmenlik Mesleğine Giriş (Introduction to Teaching Profession.) Ankara: Nobel Yayın.

Lunenberg, M. \& Korthagen, F.A.J. (2003). Teacher educators and student-directed learning. Teaching and Teacher Education 19, 29-44.

Maclellan, E. (2005). 'Academic Achievement: the role of praise in motivating students', Active Learning in Higher Education 6(3), 194-206. http://alh.sagepub.com/cgi/content/abstract/6/3/194 (Retrieved on: September 19, 2007).

Mcalpine, L. (2004). 'Designing learning as well as teaching (A research-based model for instruction that emphasizes learner practice)', Active Learning in Higher Education. 5(2), 119134.http://alh.sagepub.com/cgi/content/abstract/.(retrieved on September 19, 2007)

Niemi, H. (2002). Active learning-a cultural change needed in teacher education and schools. Teaching and Teacher Education. 18(7), 763-780. (Retrieved on 15.11.2007)

Ovando, M.N. (2001). Teachers' perceptions of a learner-centered teacher evaluation system. Journal of Personnel Evaluation in Education, 15(3), 213-231.

Saban, A. (2003) A Turkish profile of prospective elementary school teachers and their views of teaching. Teaching and Teacher Education, 19(8), 829-846. Retrieved on December 24, 2007.

Shulman, L. (1987) 'Knowledge and teaching: foundations of the new reform'. Harvard Educational Review, $57(1), 1-22$. 
Özgün-Koca A. S. \& Şen, A. İ. (2006). The beliefs and perceptions of pre-service teachers enrolled in a subjectarea dominant teacher education program about "Effective Education". Teaching and Teacher Education, 22(7), 946-960.

Tamir, P. (1988) 'Subject matter and related pedagogical knowledge in teacher education'. Teaching and Teacher Education, 4(2), 99-110.

Vries, Y. \& Beijaard, D. (1999). Teachers' conceptions of education: a practical knowledge perspective on 'good' teaching. Interchange, 30(4), 371-397.

Wilson, E.K. (2006). The impact of an alternative model of student teacher supervision: Views of the participants. Teaching and Teacher Education 22, 22-31

Yayli, D. (2008). Theory-practice dichotomy in inquiry: Meanings and preservice teacher-mentor teacher tension in Turkish literacy classrooms. Teaching and Teacher Education. 24, 889-900.

Zeichner, K. (2005). Becoming a teacher educator: a personal perspective. Teaching and Teacher Education 21: 117-124.

http://trc.ucdavis.edu/TRC/ta/tatips/activelearning.pdf

http://www.teachtech.ilstu.edu/additional/tips/newActive.php

http://www.indiana.edu/ icy/document/active_learning_techniques.pdf 


\title{
ÖZET
}

\section{Öğretmen Eğitiminde Bir Araştırma: Etkinliklere Dayalı Öğretimin Öğretmen Adaylarının Başarısındaki Etkisi}

\begin{abstract}
Amaç ve Önem: Öğretmen eğitiminde öğretmen adaylarının eğitiminde kullanılan öğretim yaklaşımlarından biri de etkinliklere dayalı öğretimdir. Briggs'e (2005) göre, yükseköğretimdeki değişimler finansman, kurumlar arasında rekabet, teknoloji kullanımında artı ve öğrenme merkezli eğitime doğru değişiklikleri kapsamaktadır. Buna dayalı olarak, sözkonusu yenilikler ve gelişmeler yükseköğretimde öğretim stratejilerini de etkileyebilir. Yaylı (2008)'nın çalışmasında da belirtildiği gibi son zamanlarda öğretmen eğitiminde gerçek sınıf koşullarında ne öğretileceğinden nasıl öğretileceğine doğru bir hareketlilik görülmektedir (Anders, Hoffman, \& Duffy, 2000; Short \& Burke, 1989; Zeichner, 1983). Yeni paradigmalar, eğitimde öğrenen merkezliyi öne çıkaran ve bilgiyi anlamlı bir biçimde yapılandıran öğrenme ve öğretme yöntemlerinin yapılandırmacı teorisi ile desteklenmiştir. Bu da öğrenmenin aktif ve sosyal bir süreç olmasını gerektirir. Ovando' nun (2001) da belirttiği gibi, öğrenen merkezli sistemin odak noktası aynı zamanda aktif öğrenme süreci ve yapılandırmacı yaklașım ile ilgili çalışmalarda da vurgulandığı üzere öğrenendir. Bu çalışma etkinliğe dayalı öğretimin öğretmen adaylarının öğrenme ürünlerinde ve bakış açıları üzerindeki etkisini araştırmıştır. Araştırmada temel olarak şu sorulara cevap aranmıştır: (1) Öntest sonuçlarına göre deney grubu ve kontrol grubu arasında istatistiksel bir farklılık var mıdır? (2) Sontest sonuçlarına göre deney grubu ve kontrol grubu arasında istatistiksel bir farklılık var mıdır? (3) Deney grubunun ön ve sontestleri arasında anlamlı bir farklılık var mıdır? (4) Kontrol grubunun ön ve sontestleri arasında anlamlı bir farklılık var mıdır? (5) Deney ve kontrol grubunda bulunan öğretmen adaylarının kullanılan öğretim yaklaşımları ve uygulamalarına ilişkin görüşleri nelerdir?
\end{abstract}

Yöntem: Bu amaca ulaşmak için, deney grubu üzerinde etkinlik temelli eğitim, kontrol grubu üzerinde ise geleneksel yaklaşım kullanılmıştır. Araştırmada nitel ve nicel araştırma yöntemleri kullanılmıştır. Nicel olarak deneysel desen, nitel olarak açık uçlu sorulardan yararlanılmıştır. Çalışma grubu 2006-2007 akademik yılında Gazi Üniversitesinde "Öğretimde Planlama ve Değerlendirme" dersine devam eden öğrenciler oluşturmuştur. Deney grubu 24, kontrol grubu 26 öğrenciden oluşmaktadır ve öğretmen eğitimi programlarında üçüncü yıllarını tamamlamış olmalarına önem verilmiştir.

Bulgular: Araştırmanın bulgularına göre, deney ve kontrol gruplarının ön-test sonuçları arasında anlamlı bir farklılık bulunmamıştır. Bu istatistiksel sonuçlar benzer araştırma sonuçlarından farklıdır ve bu nedenle sonuçlar öğretmen eğitimi programları bağlamında değerlendirilebilir.

Tartışma, Sonuç ve Öneriler: Araştırma sonuçlarına göre, deney grubunda ve kontrol gruplarındaki öğretmen adaylarının yapılan öğretim etkinlikleri sonucunda ön ve son test puan ortalamaları arasında anlamlı bir farklılık bulunmamıştır. Başka bir ifadeyle, yapılan istatistiksel analiz sonuçlarına göre etkinlik destekli öğretim ile geleneksel öğretim uygulanan gruplarda yer alan öğretmen adaylarının ön test ve son test puan ortalamaları arasında farklılık bulunmamıștır. Diğer taraftan, çalışma sonuçları aynı zamanda öğretmen adaylarının etkinlik destekli öğretim yapılan dersleri yararlı buldukları ve kavradıklarını gösteren bulgulara da işaret etmektedir. Ayrıca, çalışmaya katılan öğretmen adayları, uygulanan etkinliklerin bilişsel faydalarından çok, eğlenceli olması, grupla çalışma olanakları vs. gibi diğer boyutlarını vurgulamışlardır. 